\title{
Patients Presenting to the Emergency Unit with Gynaecological Lower Abdominal Pain, with and without Pathological Clinical Findings - Service Utilisation, Pain History, Implications
}

\author{
Patientinnen mit gynäkologisch bedingten Unterbauchschmerzen mit und ohne Organbefund \\ in der Notfallambulanz - Inanspruchnahme, Schmerzanamnese, Konsequenzen
}

Authors

Affiliations
F. Siedentopf ${ }^{1}$, E. Wowro ${ }^{2}$, M. Möckel ${ }^{3}$, H. Kentenich ${ }^{4}$, M. David ${ }^{5}$

The affiliations are listed at the end of the article.

\begin{abstract}
Key words
- emergency management

- lower abdominal pain

- women

- gynaecology

Schlüsselwörter

- Notfallversorgung

- Unterbauchschmerzen

- Frauen

- Gynäkologie
\end{abstract}

Deutsche Version unter: http://dx.doi.org/ 10.1055/s-0042-104929

\begin{abstract}
received 19.10.2015
revised 4.3.2016

accepted $\quad 6.3 .2016$
\end{abstract}

\section{Bibliography}

Dol http://dx.doi.org/ 10.1055/s-0042-104929

Geburtsh Frauenheilk 2016; 76: 952-959 @ Georg Thieme Verlag KG Stuttgart · New York . ISSN 0016-5751

\section{Correspondence}

Prof. Dr. med. Matthias David Charité Universitätsmedizin Berlin

Campus Virchow-Klinikum Klinik für Gynäkologie

Augustenburger Platz 1

13353 Berlin

matthias.david@charite.de

\section{Abstract \\ $\nabla$}

Introduction: Few studies have evaluated the utilisation of emergency gynaecological services, although lower abdominal pain (LAP) is one of the most common symptoms prompting emergency presentation. Although such pain may be caused by potentially life-threatening gynaecological diseases, very often no clinical cause is found. The aim of this study was to describe the characteristics of emergency presentations in order to enable quicker identification of real emergencies in routine clinical practice.

Materials and Methods: Standardised, so-called first aid cards of 1066 consecutive patients with LAP presenting acutely to one emergency unit were analysed in this retrospective, cross-sectional study.

Results: Over one third of cases did not constitute actual medical emergencies on objective criteria, with investigations yielding "no pathological findings". Parameters were identified that more often lead to hospital admission, e.g. palpation of a mass/resistance or at least one pathological ultrasound finding. In addition, it was found that symptoms of longer duration (average 8 days), and not only acute LAP, were also often experienced by patients as emergencies.

Conclusion: A diagnosis of "no pathological findings", which was common in our study, suggests a subjective experience of an emergency from the patient's point of view, although the possibility of unrecognised pathology has to be borne in mind. Apart from functional disorders, the origins of symptoms may include psychosomatic causes and psychosocial problems, which cannot be further defined in the emergency care setting. Also, the phenomenon of increased utilisation of emergency services parallel to the assumed opening hours of routine outpatient care facilities must be seen in a critical light.

\section{Zusammenfassung}

$\nabla$

Einleitung: Nur wenige Studien untersuchen die Inanspruchnahme gynäkologischer Notfallversorgung. Unterbauchschmerzen gehören dabei zu den häufigsten Symptomen, mit denen sich Frauen in der Rettungsstelle vorstellen. Hinter solchen akut auftretenden Schmerzen können sich potenziell lebensbedrohliche gynäkologische Erkrankungen verbergen. Oftmals lässt sich jedoch kein klinisches Korrelat für die abdominellen Schmerzen finden. Das Studienziel war die Erfassung der Charakteristika relevanter Notfälle, um so im klinischen Alltag eine schnellere Identifizierung möglich zu machen.

Material und Methoden: Im Rahmen einer retrospektiven Querschnittsstudie wurden die standardisierten Erste-Hilfe-Scheine von 1066 konsekutiven Patientinnen mit Unterbauchschmerzen ausgewertet, die sich akut in einer klinischen Notfallambulanz vorstellten.

Ergebnisse: In mehr als einem Drittel der Fälle ließ sich ein medizinischer Notfall nicht objektivieren, vielmehr ergab die Diagnostik „keinen Organbefund“. Es ließen sich Parameter herausarbeiten, die eher zu einer stationären Aufnahme führten wie z.B. Palpation einer Resistenz oder Nachweis mindestens eines pathologischen Sonografiebefunds. Des Weiteren werden durchaus nicht nur akute Unterbauchschmerzen als Notfall empfunden, sondern teilweise länger bestehende Beschwerden angegeben (Mittelwert 8 Tage).

Schlussfolgerung: Die in unserer Untersuchung häufig gestellte Diagnose „keine pathologischen Organbefunde“ weist auf einen subjektiven Notfall aus Sicht der Patientinnen hin, wobei zu bedenken ist, dass es sich auch um unerkannte Pathologie handeln könnte. Hintergrund der Beschwerden könnten neben funktionellen Störungen auch psychosomatische Ursachen sowie psychosoziale Probleme sein, die im Notaufnahmesetting letztlich nicht geklärt werden können. Da- 
rüber hinaus stellt die hohe Inanspruchnahme der Notaufnahme parallel zu angenommenen Öffnungszeiten regulärer ambulanter Versorgungsstrukturen ein Phänomen dar, das kritisch betrachtet werden sollte.

\section{Introduction}

$\nabla$

Only few studies have investigated the utilisation of emergency gynaecological services.

The number of patients of both sexes treated in emergency units annually in Germany is estimated at between 12 and 16 million, although an exact number has not been recorded [4,8]. Lower abdominal pain (LAP) is one of the most common symptoms prompting women to present to an emergency unit. Causes of such acute abdominal pain include potentially life-threatening gynaecological diseases such as extrauterine pregnancy, adnexal torsion or tuboovarian abscess. However, very often no clinical or paraclinical correlate for the pain is found. In the literature the term non-specific abdominal pain (NSAP) is often used [10]. The prevalence of NSAP in the emergency unit is quoted between 21 and $34 \%$ for both men and women, and for patients younger than 50 years of age it is as high as $40 \%$, making this one of the most common diagnoses overall among patients with abdominal pain [14,21].

After exclusion of specific causes of abdominal pain a conservative, expectant management approach or an elective diagnostic laparoscopy may be considered. In a study by Morino et al. [24] it was shown that only $55 \%$ of emergency unit patients with abdominal pain and no pathological findings, who initially underwent close observation, subsequently required operative treatment. Chronic lower abdominal pain without pathological findings can be regarded as psychosomatic. Affected patients have more psychopathology than the normal population with e.g. depression and anxiety disorders occurring more commonly $[3,22]$. This study analysed the utilisation of emergency gynaecological services by women with LAP. Particular attention was given to the examination findings of hospital admissions in whom no pathology explaining their symptoms was found. Through defining these characteristics we aimed to enable quicker identification of this group of patients in routine clinical practice. The research questions were formulated as follows:

1. How commonly do women with LAP utilise emergency services?

2. What are the demographics of this patient group?

3. What time of day do patients attend the emergency unit, and is there seasonal variation?

4. How many gynaecological hospital admissions are there?

5. How often are there no pathological findings to explain symptoms among women presenting to the emergency unit with LAP?

\section{Study Population and Methods}

Study population

This was a retrospective, cross-sectional study in which the standardised, so-called first aid cards of all patients receiving acute gynaecological care at the Virchow Hospital campus of the Charité between the 01.01.2009 and 21.12.2009 (12 months) were analysed.

\section{Analysed variables}

Clinical history of gynaecological pain and details of other pain were captured, as were results of the clinical examination and ultrasound investigation, and further parameters including results of pregnancy tests, body temperature, haemoglobin level, leukocyte count, serum CRP and BHCG levels, and urine examination. Diagnoses were taken from the first aid card. The admission/discharge procedure was also recorded, i.e. whether patients were admitted to the gynaecology department, received further treatment within a different speciality department, or could be discharged home immediately after presentation in the emergency unit. Therapeutic measures carried out in the emergency unit, recommendations, prescribed discharge medications and the absence of treatment measures were all documented.

\section{Inclusion and exclusion criteria}

The variables listed above were analysed in two subgroups:

1. Patients who were admitted to the gynaecology department;

2. Patients with no apparent cause for their LAP.

Inclusion criteria were: a documented diagnosis of LAP on the first aid card. In addition the first aid card had to contain documentation of at least the history, examination findings and treatment plan by a doctor. Exclusion criteria were: intrauterine pregnancy confirmed on ultrasound; abortion following intrauterine pregnancy; LAP associated with a current bleeding disorder; current treatment for a gynaecological tumour; and LAP in the context of trauma.

\section{Statistical analysis}

In the descriptive analysis of continuous variables incidence, minimum, maximum, mean and median values were calculated. Associations between the variables history, examination findings and treatment were analysed. Dependence between variables was analysed using Pearson's $X^{2}$ test. Odds ratios with 95\% confidence intervals were calculated for selected variables. Statistical significance was assumed at an error probability of $\mathrm{p}<0.05$. Analysis of data was performed using IBM ${ }^{\circledR}$ SPSS $^{\circledR}$ Statistics, version 18 to 20 .

\section{Results}

\section{$\nabla$}

After consideration of the inclusion and exclusion criteria, a total of 1174 first aid cards (treated cases) were included in the study. This constituted $26.4 \%$ of all gynaecology patients attending the emergency unit within the study period. 86 patients presented more than once, meaning that 1066 individual patients presented to the emergency unit during the study period, of whom 980 (91.9\%) presented once, the rest presenting up to a maximum of six times. 169 patients (14.4\%) were younger than 20 years old, 791 patients (67.4\%) were between 20 and 39 years of age, and 214 patients (18.2\%) were over 40 years of age.

\section{Time of emergency unit attendance}

The number of patients presenting did not differ significantly on different days of the week $(\mathrm{p}=0.68)$. Most patient contacts oc- 


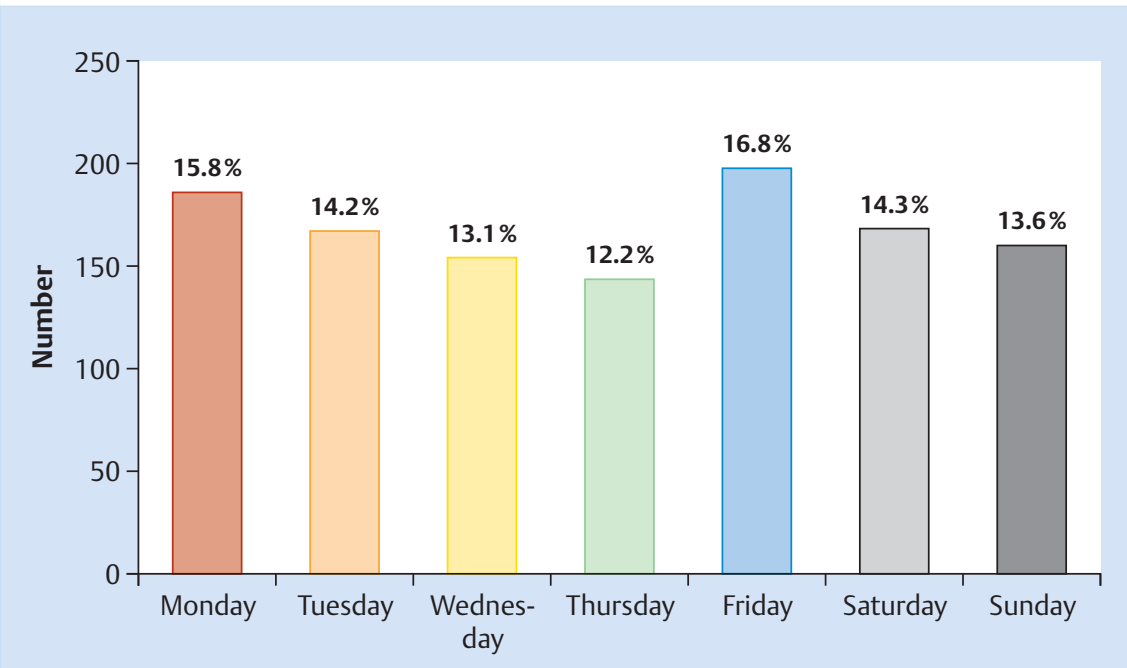

Fig. $1 \mathbf{a}$ and $\mathbf{b}$

a Day of the week of emergency unit visit.

b Time of presentation (numbers according to

24 hour clock, e.g. $12=12: 00$ to $12: 59$ ).

a

Day of the week

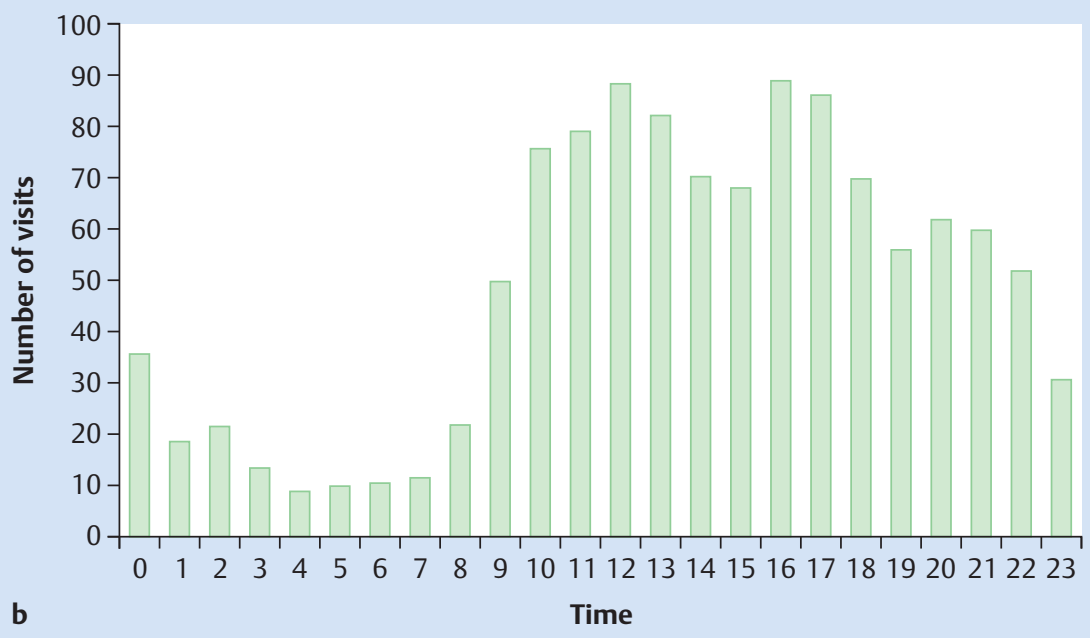

curred during the day. It was clearly shown $(\mathrm{p}<0.001)$ that emergency unit visits were not evenly distributed over the 24 hour period, but rather that more patients presented parallel to the assumed opening hours of gynaecology practices (08:00-18:00) (๑ Fig. $1 \mathbf{a}$ and $\mathbf{b}$ ).

Analysis of the annual distribution of presentation showed that significantly more patients presented in summer (28.8\%) compared to the other seasons (spring $23.7 \%$, autumn $24.2 \%$, winter $23.2 \%)(p=0.02)$.

\section{Pain history}

The severity of LAP was documented on history in 116 cases (9.9\%): in 23 patients (2\%) it was "mild", in 16 (1.4\%) "moderate", in $73(6.2 \%)$ "severe" and in 4 patients $(0.3 \%)$ it was documented as "very severe". The type/quality of LAP was documented in 275 cases (23.4\%): cramping pain was most common (8\%), followed by pulling/dragging (6.3\%), stabbing/twinging (4\%) and pressing pain $(3.7 \%)$. Localisation of LAP was documented in 502 patients (42.8\%). Duration of pain was documented in 930 cases (78.4\%) with a mean of 8.4 days (median 1 day) ( Fig. 2). Severity and quality of pain were estimated by the attending doctor on the basis of the clinical history.

Details of other symptoms in addition to the main symptom, LAP, are shown in $\triangle$ Table 1. Problems with micturition were most common (e.g. dysuria, increased micturition frequency, haematuria etc.).

\section{Diagnoses and clinical findings}

No diagnosis was documented in 86 cases (7.3\%). 85.5\% were given one diagnosis, 81 cases (6.9\%) 2 diagnoses, and in 3 cases $(0.3 \%)$ three diagnoses from various diagnosis categories were documented. Independent of age, the most common diagnosis was "no evidence of a gynaecological or infectious cause of the LAP" ( $\mathrm{n}=418$ patients, $35.6 \%)$ followed by ovarian cysts $(>3 \mathrm{~cm}$ ) ( $n=188,16 \%$ ), urinary tract infections (UTI, $n=91,7.8 \%$ ) and adnexitis ( $n=90,7.7 \%$ ). The most common three specific diagnoses/ clinical findings, grouped according to patient age, were:

1. Patients under 20 years of age: ovarian cysts $(>3 \mathrm{~cm})(22.4 \%)$, pelvic inflammatory disease (7.7\%), appendicitis (7.1\%).

2. Patients between 20 and 39 years of age: ovarian cysts $(>3 \mathrm{~cm})$ (18.1\%), suspected ectopic pregnancy (9.0\%) followed by adnexitis and UTI ( $8.5 \%$ each).

3. Patients 40 years and older: myomas (11.4\%), ovarian cysts $(>3 \mathrm{~cm})(10.4 \%)$, UTI (10.0\%).

\section{Hospital admission}

Immediate gynaecological hospital admission occurred in 231 cases (19.7\%) with an appointment for hospital admission at a 


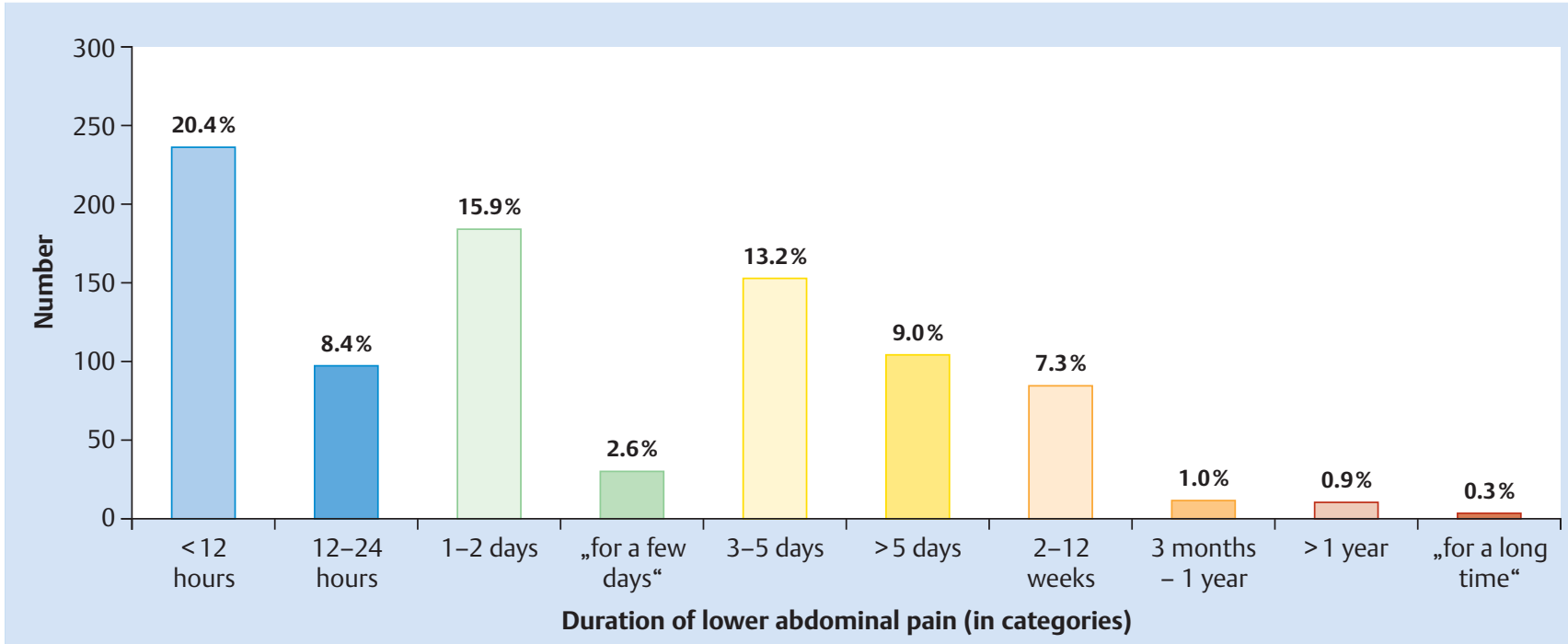

Fig. 2 Duration of pain, taking acute LAP into account.

Table 1 Presence of symptoms other than LAP.

\begin{tabular}{|c|c|c|c|}
\hline Other symptoms & Number & Percentage & Total (n, \%) \\
\hline Micturition problems & & & $529(45.1 \%)$ \\
\hline Dyes & 132 & 25.0 & \\
\hline$>$ no & 397 & 75.0 & \\
\hline Problems with defecation & & & $522(44.5 \%)$ \\
\hline - yes & 101 & 19.3 & \\
\hline no & 421 & 80.7 & \\
\hline Nausea and/or vomiting & & & $398(33.9 \%)$ \\
\hline$\checkmark$ yes & 194 & 48.7 & \\
\hline$>$ no & 204 & 51.3 & \\
\hline $\begin{array}{l}\text { Pathological vaginal } \\
\text { discharge }\end{array}$ & & & $243(20.7 \%)$ \\
\hline D yes & 37 & 15.2 & \\
\hline no & 206 & 84.8 & \\
\hline
\end{tabular}

later date being arranged in 28 cases (2.4\%). 74 patients (6.3) refused hospital admission. Inpatient gynaecological management was not indicated in 714 cases (60.8\%) and 162 patients (13.8\%) were managed further in a different speciality department. An analysis of the correlation between gynaecological hospital admission and the parameters "transport to hospital" and "pain history" showed that patients who were brought to hospital by "acute transport" (patient transport, ambulance or fire brigade) were admitted 2.2 times more often. A significant association was also found with severe pain (OR 2.6; $1.1-6.3$ ) but not with stated duration of pain ( Table 2 ).

- Tables 3 and $\mathbf{4}$ show examination findings that were associated with significantly higher rates of hospital admission. Admission was most common with abdominal tenderness, tender internal pelvic organs, cervical excitation tenderness, abdominal guarding or a palpable mass/resistance.

Pathological examination findings of the vagina and vulva, pathological vaginal discharge and pathological findings on rectal examination had no effect on hospital admission rate (Table 4), likewise the results of urine examination $(\mathrm{p}=0.3)$.
Subgroup of patients with LAP and no pathological findings In 418 patients (35.6\%) no gynaecological or other cause of their symptoms was found. Time of presentation $(p=0.1)$, age distribution $(p=0.26)$ and duration of pain $(p=0.32)$ did not differ from the overall study population. Mean duration of pain in this subgroup of patients was 9.9 days, SD 42.3. A causative diagnosis was found significantly more often in patients reporting severe LAP compared to those without severe pain ( 77.9 vs. $56.41 \%$; $\mathrm{p}=0.016$ ).

Reported duration of pain did not influence the finding of a gynaecological diagnosis, which for acute LAP $(<48 \mathrm{~h})$ was independent of whether pain had been present for less than 12 hours, less than 24 hours or less than 48 hours. No gynaecological diagnosis responsible for symptoms was found in $41.7 \%$ of patients with pain duration of more than 8 weeks, while for patients with a shorter duration of pain the figure was $37.7 \%$, $(p=0.54)$.

A cause of symptoms was found significantly more often in patients with pathological micturition than in those without $(p<0.001)$. There was no association between presumed cause of pain and reported nausea and/or vomiting (OR 1.0, 95\% CI 0.7, $1.5)$, problems with defecation (e.g. constipation, diarrhoea, dyschezia, haematochezia) (OR 0.7, 95\% CI 0.4, 1.1), pathological vaginal discharge (OR $1.3,95 \% \mathrm{CI} 0.6,2.6$ ) or pathological cardiovascular response (OR 2.2, 95\% CI 0.4, 13.3).

Hospital admission was thought to be indicated in 17 patients without pathological clinical findings (4.1\%). This was the case 17 times more often in patients with the diagnosis "with pathological findings" (95\% CI 10.3, 28.5, p < 0.001).

- Table 5 shows the measures taken or recommendations made for the 418 patients in whom no cause of the symptoms was found.

\section{Discussion}

$\nabla$

Approximately a quarter of patients attending the emergency unit reported lower abdominal pain as their reason for presentation. In other studies 4.5 to $6 \%$ of emergency unit patients re- 
Table 2 Gynaecological hospital admission for mode of transport and pain history.

\begin{tabular}{|c|c|c|c|c|}
\hline \multirow{2}{*}{$\begin{array}{l}\text { Transport and } \\
\text { pain history }\end{array}$} & \multicolumn{3}{|c|}{ Inpatient management } & \multirow[t]{2}{*}{ Odds ratio } \\
\hline & $\begin{array}{l}\text { yes } \\
\text { (\%) }\end{array}$ & $\begin{array}{l}\text { no } \\
\text { (\%) }\end{array}$ & $\begin{array}{l}\text { total } \\
\text { (n) }\end{array}$ & \\
\hline "Acute transport" & & & & $\begin{array}{l}2.2(95 \% \mathrm{Cl} 1.3 \\
3.8), \mathrm{p}=0.002\end{array}$ \\
\hline yes & 44.9 & 55.1 & 69 & \\
\hline$>$ no & 26.7 & 73.3 & 442 & \\
\hline LAP for $<12$ hours & & & & $\begin{array}{l}1.1(95 \% \mathrm{Cl} 0.8 \\
1.5), \mathrm{p}=0.7\end{array}$ \\
\hline - yes & 30.5 & 69.5 & 220 & \\
\hline no & 29.3 & 70.7 & 618 & \\
\hline LAP for $<24$ hours & & & & $\begin{array}{l}1.2(95 \% \mathrm{Cl} 0.9 \\
1.6), p=0.3\end{array}$ \\
\hline$>$ yes & 31.7 & 68.3 & 322 & \\
\hline$>$ no & 28.3 & 71.7 & 516 & \\
\hline LAP for $<48$ hours & & & & $\begin{array}{l}1,1(95 \% \mathrm{Cl} 0.8 \\
1.4), p=0.7\end{array}$ \\
\hline - yes & 30.1 & 69.9 & 472 & \\
\hline$>$ no & 29.0 & 71.0 & 366 & \\
\hline Severe LAP & & & & $\begin{array}{l}2.6(95 \% \mathrm{Cl} 1.1 \\
6.3), \mathrm{p}=0.03\end{array}$ \\
\hline - yes & 51.4 & 48.6 & 72 & \\
\hline no & 28.6 & 71.4 & 35 & \\
\hline
\end{tabular}

ported abdominal pain $[14,30]$ and in one study it was the main symptom in 4 to $8 \%$ of hospital admissions [15].

In the current study population patients between 20 and 39 years of age had a disproportionately high rate of emergency unit attendance. A possible explanation for this is that diseases associated with LAP, e.g. genitourinary infections, more commonly affect younger women [6].

The majority of patients only made use of the emergency unit once during the study period, with repeat presentations accounting for approx. $8 \%$ of visits. Gilling-Smith et al. found a similar proportion of repeat presentations for patients with LAP [12].

Approximately $42 \%$ of patients in our study presented within the presumed normal opening hours (08:00-18.00) of practice gynaecologists. This rate was higher in other studies [7,23]. In contrast, the daily and weekly profiles of patient contacts in our study correspond to those of a study from the Erlangen University Hospital [9].

In 2012 there was an average of 15.9 gynaecologists per 100000 Berlin residents. On a regional level this is a comparatively high concentration of gynaecologists, e.g. the concentration in Brandenburg is relatively low at $10.3 / 100000$. The gynaecologist concentration in Berlin compares with the average distribution in urban centres, whereas in rural and surrounding areas the figures for 2012 were 9 to $10 / 100000$ residents [19]. Borde et al. [5] postulated that the threshold for utilising clinical emergency services was lower than that for attending general and specialist practices. This was thought to be the case particularly in patients with an immigrant background, since these patients confront access barriers to routine health care services and are more familiar with hospital institutions.

We were able to demonstrate that significantly more patients attended the emergency unit in the summer months of June, July and August than during other seasons. Bianchi-Demicheli et al. [2] showed positive correlation between the incidence of LAP
Table 3 Gynaecological hospital admission dependant on examination findings.

\begin{tabular}{|c|c|c|c|c|}
\hline \multirow{2}{*}{$\begin{array}{l}\text { Examination } \\
\text { findings }\end{array}$} & \multicolumn{3}{|c|}{ Inpatient treatment } & \multirow[t]{2}{*}{ Odds ratio } \\
\hline & $\begin{array}{l}\text { yes } \\
(\%)\end{array}$ & $\begin{array}{l}\text { no } \\
(\%)\end{array}$ & $\begin{array}{l}\text { total } \\
\text { (n) }\end{array}$ & \\
\hline $\begin{array}{l}\text { Abdominal } \\
\text { tenderness }\end{array}$ & & & & $\begin{array}{l}2.3(95 \% \mathrm{Cl} 1.6, \\
3.3), \mathrm{p}<0.001\end{array}$ \\
\hline byes & 37.5 & 62.5 & 283 & \\
\hline$>$ no & 20.6 & 79.4 & 291 & \\
\hline $\begin{array}{l}\text { Tender } \\
\text { adnexia/uterus }\end{array}$ & & & & $\begin{array}{l}5.6(95 \% \mathrm{Cl} 4.0, \\
8.0), \mathrm{p}<0.001\end{array}$ \\
\hline$\rightarrow$ yes & 54.9 & 45.1 & 275 & \\
\hline$>$ no & 17.7 & 82.3 & 417 & \\
\hline $\begin{array}{l}\text { Cervical excitation } \\
\text { tenderness }\end{array}$ & & & & $\begin{array}{l}6.0(95 \% \mathrm{Cl} 3.7 \text {, } \\
9.9), \mathrm{p}<0.001\end{array}$ \\
\hline yes & 65.0 & 35.0 & 80 & \\
\hline no & 23.5 & 76.5 & 574 & \\
\hline $\begin{array}{l}\text { Abdominal } \\
\text { guarding }\end{array}$ & & & & $\begin{array}{l}3.3(95 \% \mathrm{Cl} 1.6 \\
6.8), p=0.001\end{array}$ \\
\hline yes & 60.0 & 40.0 & 35 & \\
\hline$>$ no & 31.2 & 68.8 & 298 & \\
\hline $\begin{array}{l}\text { Palpable } \\
\text { mass/resistance }\end{array}$ & & & & $\begin{array}{l}8.9(95 \% \mathrm{Cl} 3.9, \\
20.3), p<0.001\end{array}$ \\
\hline$\rightarrow$ yes & 66.0 & 34.0 & 47 & \\
\hline$>$ no & 17.9 & 82.1 & 84 & \\
\hline $\begin{array}{l}\text { Rebound } \\
\text { tenderness }\end{array}$ & & & & $\begin{array}{l}2.5(95 \% \mathrm{Cl} 1.0, \\
6.1), p=0.04\end{array}$ \\
\hline - yes & 42.9 & 57.1 & 42 & \\
\hline$>$ no & 23.1 & 76.9 & 52 & \\
\hline
\end{tabular}

\% stated: hospital admissions per clinical examination finding

Table 4 Gynaecological hospital admission dependant on the gynaecological examination

\begin{tabular}{|c|c|c|c|c|}
\hline \multirow{2}{*}{$\begin{array}{l}\text { Pathological } \\
\text { clinical findings }\end{array}$} & \multicolumn{3}{|c|}{ Inpatient treatment } & \multirow[t]{2}{*}{ Odds ratio } \\
\hline & $\begin{array}{l}\text { yes } \\
(\%)\end{array}$ & $\begin{array}{l}\text { no } \\
(\%)\end{array}$ & $\begin{array}{l}\text { total } \\
\text { (n) }\end{array}$ & \\
\hline $\begin{array}{l}\text { Vaginal } \\
\text { examination }\end{array}$ & & & & $\begin{array}{l}0.5(95 \% \mathrm{Cl} 0.2 \\
1.5), p=0.2\end{array}$ \\
\hline yes & 17.4 & 82.6 & 23 & \\
\hline$>$ no & 29.7 & 70.3 & 834 & \\
\hline Use of speculum & & & & $\begin{array}{l}1.3(95 \% \mathrm{Cl} 0.6 \\
2.8), p=0.03\end{array}$ \\
\hline yes & 41.7 & 58.3 & 72 & \\
\hline$>$ no & 29.1 & 70.9 & 798 & \\
\hline $\begin{array}{l}\text { Pathological } \\
\text { vaginal discharge }\end{array}$ & & & & $\begin{array}{l}1.5 \text { (95\% Cl 0.9, } \\
2.5), p=0.1\end{array}$ \\
\hline$\checkmark$ yes & 38.9 & 61.1 & 72 & \\
\hline$>$ no & 29.4 & 70.6 & 565 & \\
\hline Rectal examination & & & & OR not calculable \\
\hline$\checkmark$ yes & 20.0 & 80.0 & 15 & \\
\hline$>$ no & 0.0 & 0.0 & 0 & \\
\hline
\end{tabular}

\% stated: hospital admissions per clinical examination finding

and ambient temperature. Patients with abdominal pain of unknown cause presented around 2.3 times more often on warm days. The possible reason for this was thought to be the weather's sensitising effect on the occurrence and perception of pain, whereby e.g. changes to the expansion and contraction of tissues, changes to the balance/equilibrium of neurotransmitters, but al- 
Table 5 Comparison of management and recommendations between patients without pathological findings or demonstrable cause of symptoms and those with clinical findings/diagnoses.

\begin{tabular}{|c|c|c|c|c|}
\hline Management/recommendations & $\begin{array}{l}\text { No cause of symptoms } \\
\text { (\%) }\end{array}$ & $\begin{array}{l}\text { Cause of symptoms } \\
\text { identified (\%) }\end{array}$ & Total (n) & Odds ratio \\
\hline $\begin{array}{l}\text { Further consultation received/ } \\
\text { recommended }\end{array}$ & & & & $2.3(95 \% \mathrm{Cl} 1.7,3.1), \mathrm{p}<0.001$ \\
\hline - yes & 52.2 & 47.8 & 205 & \\
\hline no & 32.1 & 67.9 & 969 & \\
\hline Drug therapy received & & & & $0.3(95 \% \mathrm{Cl} 0.2,0.4), \mathrm{p}<0.001$ \\
\hline > yes & 20.6 & 79.4 & 447 & \\
\hline no & 44.8 & 55.2 & 727 & \\
\hline Follow-up recommended & & & & $1.5(95 \% \mathrm{Cl} 1.2,2.0), \mathrm{p}=0.001$ \\
\hline - yes & 42.1 & 57.9 & 411 & \\
\hline no & 32.1 & 67.9 & 763 & \\
\hline Treatment recommended & & & & $0.5(95 \% \mathrm{Cl} 0.3,0.9), \mathrm{p}=0.012$ \\
\hline D yes & 26.3 & 73.8 & 80 & \\
\hline$>$ no & 41.6 & 58.4 & 291 & \\
\hline Other investigation recommended & & & & $1.7(95 \% \mathrm{Cl} 0.9,3.1), \mathrm{p}=0.08$ \\
\hline - yes & 40.8 & 59.2 & 304 & \\
\hline no & 29.0 & 71.0 & 62 & \\
\hline Operative treatment recommended & & & & $0.6(95 \% \mathrm{Cl} 0.3,1.3), p=0.2$ \\
\hline - yes & 31.6 & 68.4 & 38 & \\
\hline no & 43.0 & 57.0 & 384 & \\
\hline
\end{tabular}

so subjective aspects could influence pain perception [2]. Clothing and the frequency of sexual intercourse could also possibly play a role.

Severe or very severe pain and pain existing for less than 24 to 48 hours were clinical details indicating appropriate utilisation of the emergency unit, i.e. fulfilling the actual role of emergency services. Other studies have mostly shown a much higher proportion of patients with severe pain [26] or pain present for less than 24 hours $[5,7,12,28]$.

Over half the patients in our study presented with symptoms of over 48 hours duration, and as such can be classified as "non acute". A regular gynaecology appointment would have been possible for these patients.

LAP of at least 3 months duration is defined as chronic, though some authors use a definition of at least 6 months (www.iasppain.org). In the current study $2 \%$ of patients had had pain for over 3 months. This is much lower than in other prevalence studies in the outpatient setting $[17,33]$.

This study also showed a trend towards more laboratory investigations in patients without pathological clinical findings, most probably to exclude other acute causes of pain that would have required treatment.

The most common statement by the attending doctor was that no apparent gynaecological or other cause for the symptoms could be found. Other common diagnoses were ovarian cysts and inflammatory conditions of the genitourinary tracts. When compared to other studies, here our findings were contradictory: estimates of pelvic inflammatory disease were lower in some cases [18] and higher in others [6]. The proportion of non-inflammatory ovarian and tubal disorders in our study was higher than in studies by Asch et al. [1], Curtis et al. [6] and Jearwattanakanok et al. [18]. Pokharel et al. [29] showed a similar proportion of ovarian cysts with or without complications such as torsion. Kurt et al. [20] found a much higher proportion of non-inflammatory ovarian and tubal disorders. A possible reason for this discrepancy is the drainage area population (university hospital), with a tendency towards sicker patients. This is particularly the case when various levels of care are concurrently available at one facility or are easily accessible in a particular area [32], which was the case for our study setting.

In our study hospital admission was more common ( $20 \%$ overall) for diseases that constitute typical gynaecological emergencies as well as in the presence of a mass/tumour and for inflammatory disorders requiring late operative intervention or intravenous antibiotic treatment. Other study groups have had similar findings with 20 to $34 \%$ of abdominal pain patients requiring hospital admission $[12,14,28]$. Severity and duration of pain were not associated with hospital admission in these studies.

In around one third of our patients there were no clinical/pathological findings explaining their symptoms. A review of the published literature reveals similar data on the incidence of non-specific abdominal pain. Stated percentages of NSAP among emergency unit patients lie between 25 and 44\% [11,13,14,20,30, 34]. Only one Greek study found lower rates of 8 to $16 \%$ in patients of both sexes [28]. In a study by Nimnuan et al. [25] 52\% of included patients of both sexes were found to have "medically unexplained" symptoms with the highest prevalence (66\%) among gynaecology patients. Non-specific, functional and somatoform physical symptoms are thought to occur in $4-10 \%$ of the general population and around $20 \%$ of general practice patients. They are reported 1.5 to 3 times more often by women than men, independent of age. The most common manifestations are pain in various locations, organ dysfunction, fatigue and exhaustion [16, 27,31].

\section{Limitations}

1. Study design: retrospective data analysis.

2. Data quality: The documentation on the first aid cards was not according to strict stipulations. To some extent a marked qualitative and quantitive variation in documentation was found; an information bias was created through imprecise and incomplete recording of history, investigations and treatment. However comparability of data was achieved through uniform coding of documented information as variables. 
3. Scientific quality of documentation: The first aid card is a tool for routine documentation and was not primarily conceptualised for scientific research. Comprehensive and precise documentation of medical care, as desirable for research purposes, is for various reasons mostly not possible within the framework of the emergency doctor's duties.

4. The examining doctors were specialist trainees from all stages of training, thus it can be assumed that clinical examination and diagnosis were of very variable quality.

5. Patients were not followed up with respect to the correctness of their clinical diagnoses, i.e. whether the presumed diagnosis was confirmed or not, nor whether the recommended treatment was carried out.

\section{Conclusions}

It is the duty of emergency unit doctors to differentiate apparent emergencies from actual emergencies using a combination of clinical assessment/examination and targeted investigations. In over a third of cases in our study a medical emergency could not be objectively confirmed, on the contrary the clinical examination and investigations in these cases showed "no pathological findings". These were subjective emergencies, seen as such from the patient's perspective, though it must be taken into consideration that there may have been some undiagnosed pathology. These symptoms may have their basis in functional disorders or psychosomatic/psychosocial problems, which ultimately can not be better elucidated in the acute, medically oriented emergency setting; in discussion with the patient it may be possible to make recommendations for further psychosomatic workup.

Quite clearly, it is not only acute LAP but also symptoms of longer duration (mean 7 days) that are perceived as emergencies. Crucial factors for hospital admission were not so much the reported severity or duration of pain but rather the vaginal ultrasound and clinical examination findings, both of which bear considerable weight in the overall clinical assessment.

Looking beyond the individual patient, the increased utilisation of emergency services parallel to assumed opening hours of routine outpatient care structures is a phenomenon that should be seen in a critical light from a public health perspective, and should prompt structural changes.

\section{Conflict of Interest}

$\nabla$

None.

\author{
Affiliations \\ ${ }^{1}$ Frauenklinik, Martin-Luther-Krankenhaus, Berlin \\ 2 Vivantes, Auguste-Viktoria-Klinikum, Klinik für Neurologie, Berlin \\ ${ }^{3}$ Charité - Universitätsmedizin Berlin, Campus Virchow-Klinikum und Campus \\ Mitte, Arbeitsbereich Notfallmedizin/Rettungsstellen mit Aufnahme- \\ stationen und CPUs, Berlin \\ ${ }^{4}$ Fertility Center Berlin, Berlin \\ ${ }^{5}$ Charité - Universitätsmedizin Berlin, Campus Virchow-Klinikum, \\ Klinik für Gynäkologie, Berlin
}

\section{References}

1 Asch E, Shah S, Kang T et al. Use of pelvic computed tomography and sonography in women of reproductive age in the emergency department. J Ultrasound Med 2013; 32: 1181-1187

2 Bianchi-Demicheli F, Ludicke F, Spinedi $F$ et al. Association between weather conditions and the incidence of emergency gynecological consultations. Gynecol Obstet Invest 2001; 51: 55-59

3 Bodden-Heidrich $R$. [Chronic pelvic pain syndrome-a multifactorial syndrome]. Zentralbl Gynakol 2001; 123: 10-17
4 Brachmann M, Geppert R, Niehues C et al. Ökonomische Aspekte der klinischen Notfallversorgung - Positionspapier der AG Ökonomie 2009. Online: http://www.dgina.de/media/veroeffent/20090729_

Positionspapier_2009_07_08_MB_F.pdf; last access: 28.05.2016

5 Borde T, Braun T, David M. Unterschiede in der Inanspruchnahme klinischer Notfallambulanzen durch deutsche Patienten/innen und Migranten/innen. Problembeschreibung, Ursachenanalyse, Lösungsansätze. Schlussbericht. Schlussbericht zum Forschungsprojekt (BMBF/Spitzenverbände der Krankenkassen, Förderkennzeichen: 01 GL 0009). Berlin: 2003. Online: http://docplayer.org/80709-Unterschiede-inder-inanspruchnahme-klinischer-notfallambulanzen-durch-deutsche -patienten-innen-und-migranten-innen.html; last access: 28.05.2016

6 Curtis KM, Hillis SD, Kieke BA jr. et al. Visits to emergency departments for gynecologic disorders in the United States, 1992-1994. Obstet Gynecol 1998; 91: 1007-1012

7 David M, Babitsch B, Klein N et al. Auswirkungen der Praxisgebühr auf die Inanspruchnahme von Notfallambulanzen. Notfall + Rettungsmedizin 2013; 16: 167-174

8 DGINA. Pressemitteilung: Zahl der Patienten in Notaufnahmen steigt immer weiter. Pressemitteilung DGINA 2010. Online: http://www. dgina.de/modules/download_gallery/dlc.php?file=70; last access: 28.05.2016

9 Dormann H, Diesch K, Ganslandt T et al. Numerical parameters and quality indicators in a medical emergency department. Dtsch Arztebl Int 2010; 107: 261-267

10 Franke $C$, Verreet P, Ohmann C et al. Klinische Standardisierung bei akuten Bauchschmerzen. Langenbeck's Archives of Surgery 1996; 381: 65-74

11 Frieling $T$. [Acute abdomen from the internal medicine point of view]. Dtsch Med Wochenschr 2009; 134: 246-250

12 Gilling-Smith C, Panay N, Wadsworth J et al. Management of women presenting to the accident and emergency department with lower abdominal pain. Ann R Coll Surg Engl 1995; 77: 193-197

13 Grundmann RT, Petersen M, Lippert $H$ et al. [The acute (surgical) abdomen - epidemiology, diagnosis and general principles of management]. Z Gastroenterol 2010; 48: 696-706

14 Hastings RS, Powers RD. Abdominal pain in the ED: a 35 year retrospective. Am J Emerg Med 2011; 29: 711-716

15 Hatipoglu S, Hatipoglu F, Abdullayev R. Acute right lower abdominal pain in women of reproductive age: clinical clues. World J Gastroenterol 2014; 20: 4043-4049

16 Hausteiner-Wiehle C, Schäfert R, Häuser W et al. S3-Leitlinie „Umgang mit Patienten mit nicht-spezifischen, funktionellen und somatoformen Körperbeschwerden“. AWMF-Reg.-Nr.051-001. Langfassung. http://www.awmf.org/leitlinien/detail/11/051-001.html, AWMF (Arbeitsgemeinschaft der Wissenschaftlichen Medizinischen Fachgesellschaften. 2012. Online: http://www.awmf.org/uploads/tx_szleitlinien/ 051-0011_S3_Nicht-spezifische_funktionelle_somatoforme_ Koerperbeschwerden_2012-04.pdf; last access: 17.06.2014

17 Jarrell JF, Vilos GA, Allaire C et al. Consensus guidelines for the management of chronic pelvic pain. J Obstet Gynaecol Can 2005; 27: 781-826

18 Jearwattanakanok K, Yamada S, Suntornlimsiri Wet al. Validation of the diagnostic score for acute lower abdominal pain in women of reproductive age. Emerg Med Int 2014; 2014: 320926

19 Kassenärztliche Bundesvereinigung. Versorgungsstrukturen „Vertragsärzte und -psychotherapeuten je 100.000 Einwohner im Jahr 2012 (nach Arztgruppen)“; Tabellen; Arztgruppe „Frauenärzte“; Region „Bundesland“ und „Kreistyp“. Online: http://www.versorgungsatlas. de/themen/versorgungsstrukturen/; last access: 18.01.2016

20 Kurt S, Uyar I, Demirtas 0 et al. Acute pelvic pain: evaluation of 503 cases. Arch Iran Med 2013; 16: 397-400

21 Lankisch PG, Mahlke R, Lübbers H. Das akute Abdomen aus internistischer Sicht. Dtsch Arztebl 2006; 103: 2179-2188

22 Latthe P, Mignini L, Gray R et al. Factors predisposing women to chronic pelvic pain: systematic review. BMJ 2006; 332: 749-755

23 Matteson KA, Weitzen SH, Lafontaine D et al. Accessing care: use of a specialized women's emergency care facility for nonemergent problems. J Womens Health (Larchmt) 2008; 17: 269-277

24 Morino M, Pellegrino L, Castagna E et al. Acute nonspecific abdominal pain: A randomized, controlled trial comparing early laparoscopy versus clinical observation. Ann Surg 2006; 244: 881-886; discussion 886-888

25 Nimnuan C, Hotopf M, Wessely S. Medically unexplained symptoms: an epidemiological study in seven specialities. J Psychosom Res 2001; 51: 361-367 
26 Niska R, Bhuiya F, Xu J. National Hospital Ambulatory Medical Care Survey: 2007 emergency department summary. Natl Health Stat Report 2010; $26: 1-31$

27 olde Hartman TC, Borghuis MS, Lucassen PL et al. Medically unexplained symptoms, somatisation disorder and hypochondriasis: course and prognosis. A systematic review. J Psychosom Res 2009; 66: 363-377

28 Pappas A, Toutouni H, Gourgiotis S et al. Comparative approach to nontraumatic acute abdominal pain between elderly and non-elderly in the emergency department: a study in rural Greece. J Clin Med Res 2013; 5: 300-304

29 Pokharel HP, Dahal P, Rai R et al. Surgical emergencies in obstetrics and gynaecology in a tertiary care hospital. JNMA J Nepal Med Assoc 2013; 52: $213-216$
30 Powers RD, Guertler AT. Abdominal pain in the ED: stability and change over 20 years. Am J Emerg Med 1995; 13: 301-303

31 Schaefert R, Hausteiner-Wiehle C, Häuser $W$ et al. Nicht-spezifische, funktionelle und somatoforme Körperbeschwerden. Dtsch Arztebl Int 2012; 109: 803-813

32 Searle J, Muller R, Slagman A et al. Überfüllung der Notaufnahmen, Gründe und populationsbezogene Einflussfaktoren. Notfall Rettungsmed 2015; DOI: 10.1007/s10049-015-0011-2

33 Siedentopf F, Kölm P, Kentenich $H$. Chronischer Unterbauchschmerz der Frau AWMF online. Leitlinien der Deutschen Gesellschaft für Psychosomatische Frauenheilkunde und Geburtshilfe (DGPfG). Online: http://www.awmf.org/leitlinien; last access: 01.01.2009

34 Verde PE, Decker F, Yang Q et al. Diagnostische Profile bei akuten Bauchschmerzen mit multinominaler logistischer Regression. GMS Med Inform Biom Epidemiol 2007; 3: Doc11 